\title{
軸対称構造物による波の散乱と波力
}

\section{SCATTERING OF WATER WAVES DUE TO VERTICAL AXISYMMETRIC BODIES AND INDUCED FORCES}

\author{
清 川 哲 志* - 小 林 浩** -日 野 幹 雄*** \\ By Tetsushi KIYOKAWA, Hiroshi KOBAYASHI and Mikio HINO
}

\section{1. 序論}

本論文は，一定水深中に置かれた軸対称構造物による 微小振幅波の散乱と構造物に作用する流体力を，固有関 数展開およびフーリエ展開などを用いて, 厳密に求める 方法について述べるものである.

従来, 構造物に作用する波力の実用算定法として有名

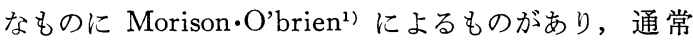
の波力計算にはこれが用いられてきた.しかし，Garrison $^{2)}$ も指摘しているように，この適用範囲は構造物の 径 $D$ と入射波の波長 $L$ との比 $D / L$ が $1 / 5$ 以下の場合 であり，構造物の大型化による波自身の変形，すなわち 回折・散乱などの影響が大きい場合には適用できない.

回折・散乱などの波の変形を考慮した理論には，大型 円筒構造物を対象とした $\mathrm{MacCamy} \cdot \mathrm{Fuchs}^{3}$ によるも

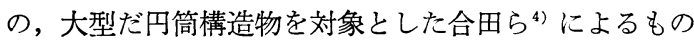
があり，これらは，いずれも速度ポテンシャルに関する 境界值問題として, 純解析的に導かれている.

これに対して, 構造物形状が複雑になると, グリーン 関数を用いてこれを核関数とする積分方程式を導き, 連 立方程式に変換して数值的に解くという方法 ${ }^{5)}{ }^{-9)}$ が一般 的である. また，最近は大型電子計算機の普及と，これ に伴う有限要素解析の流行から, 波の回折・散乱の問題 にこれを適用した例も見受けられる(10) 13).

しかし，これらはいずれも数值解析による近似解法で あり,また，大行列演算を必要とする. 特に, 有限要素 法は, 一般に無限領域を扱うのに適した方法とはいえ ず,しかも, 海洋構造物の波力の問題で必要とするのは 構造物表面のポテンシャル值のみであるのに, 構造物を 用む領域すべてについて有限要素メッシュを切る必要が

* 正会員 清水建設 (株) 研究所 海洋研究部

** 正会員 Eng. Sc. D. 清水建設 (株) 研究所主席研究員

*** 正会員 工博 東京工業大学教授 工学部土木工学科
あり，3 次元問題などでは，未知数の数は膨大なものと なる.この点を改良する試みも瀬戸14) 16) らによって行 われているが，いずれにしても著者らは，有限要素法 は，海洋構造物を解析する方法として，それほど適した ものではないと考えている.

一方，本論文で取り扱う軸対称構造物を対象とした理 論解析は, Black ${ }^{17)}$, Fenton $^{18)}$ ，松井 ${ }^{19)}$ らにより行われ ているが，これらはいずれもグリーン関数をフーリエ展 開して, フーリエ次数ごとに積分方程式を導くもので, 積分方程式の解法にあたっては，離散化手法を用いてい る. したがって, これらの解析も, やはり数值解析の一 種であるということができる.

これに対して, 本論文で示す理論は厳密解を構成する ものである.これは，固有関数展開およびフーリエ展開 によって，軸対称問題の一般解を導き，この一般解を用 いて表わした構造物表面の境界条件を,さらに固有関数 で展開することによって，一般解中の未定係数が満たす べき関係式を導くもので，これによると個々の構造物の 形状に応じて, 未定係数が満たすべき複素係数連立 1 次 方程式が得られ，これを解いて得られる係数を一般解に 代入すると，基礎方程式とすべての境界条件を満足する 厳密解が得られる。

以下，本論文ではこの理論の展開に重点を置いて述べ る.そして, 本理論を円筒構造物に適用すると, 先に述 べた MacCamy·Fuchs の解が得られる過程を示し, 本 理論が円筒の場合の MacCamy と Fuchs の理論を包含 したより一般的な理論であることを明らかにする。ま た，軸対称構造物の代表的な例として，円すい台（conical island) による回折と波力，貯油タンク型構造物の 波力などについて計算結果を示す. 


\section{2. 軸対称構造物による波の回折・散乱に関す る理論}

\section{（1）基礎方程式と一般解}

水深が一定の水域に, 海底面上に設置された頭出し軸 対称構造物があり, これに角振動数 $\omega$ の微小振幅波が 入射している，そして，入射波は，構造物によって散乱 しているものとする.

図一1 に示すように, 座標系を静水面上, 構造物中心 に原点 0 , 鉛直上方に $z$ 軸, 水平面内に $x, y$ 軸をとっ て定義する. また, 円筒座標を $x$ 軸から反時計まわりに $\theta, z$ 軸からの水平距離 $r$ をとって定義する.

軸対称構造物を対象としているので，入射波はどの方 向から来ても同じである. 便宜上, $x$ 軸の正の方向から 負の方向に進行しているものとする.

流体は非粘性・非圧縮性とし, 運動は非回転であると する.このとき, 速度ポテンシャルが存在し, 流体運動 はこれに支配される.ここでは，これを入射波のポテン シャル $\phi_{\text {in }}$ と, 散乱波のポテンシャル $\phi_{\mathrm{sc}}$ の和と考え, 軸対称構造物を取り扱う便宜上, 円筒座標で次のように 表わす.

$$
\begin{aligned}
\Phi(r, \theta, z, t)= & \frac{g H_{0}}{2 \omega}\left\{\phi_{\mathrm{in}}(r, \theta, z)\right. \\
& \left.+\phi_{\mathrm{sc}}(r, \theta, z)\right\} e^{i \omega t} .
\end{aligned}
$$

上式で入射波のポテンシャル関数 $\phi_{\text {in }}$ は既知であり， 次のように表わされる.

$$
\phi_{\text {in }}(r, \theta, z)=\frac{\cosh k_{0}(h+z)}{\cosh k_{0} h} \cdot e^{i k_{0} r \cos \theta}
$$

ここに, $H_{0}$ : 入射波高, $g$ : 重力加速度, $h:$ 水深, $i$ :
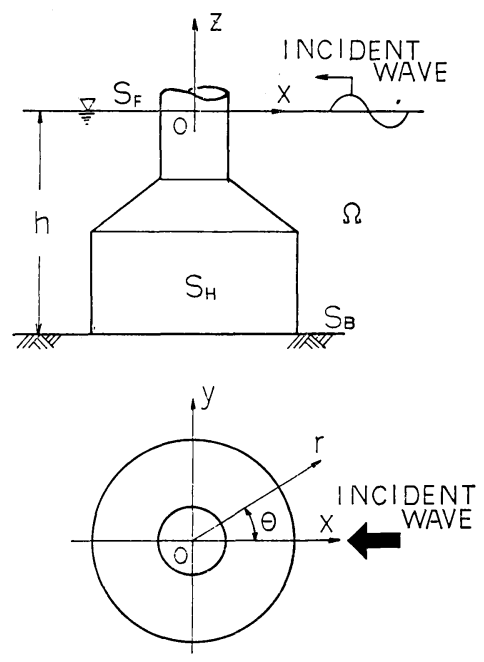

図一1 侳 標 系 の定 義
虚数単位, $k_{0}$ : 波数 ( $k_{0} \tanh k_{0} h=\omega^{2} / g$ の実正根) であ る.

散乱波のポテンシャル $\phi_{\mathrm{sc}}$ は, 次の 基礎方程式と境 界条件を満たすものとして得られる.

$$
\begin{array}{ll}
\nabla^{2} \phi_{\mathrm{sc}}=0 & (\text { in } \Omega) \\
\partial \phi_{\mathrm{sc}} / \partial z-\left(\omega^{2} / g\right) \phi_{\mathrm{sc}}=0 & \left(\text { on } S_{F}\right) \\
\partial \phi_{\mathrm{sc}} / \partial z=0 & \left(\text { on } S_{B}\right) \\
\partial \phi_{\mathrm{sc}} / \partial n=-\partial \phi_{\mathrm{in}} / \partial n & \left(\text { on } S_{H}\right) \\
\lim _{r \rightarrow \infty} r^{1 / 2}\left(\partial \phi_{\mathrm{sc}} / \partial r-i k_{0} \phi_{\mathrm{sc}}\right)=0 \cdots \cdots
\end{array}
$$

ここに, $\nabla^{2}:$ ラプラシアン, $\Omega$ : 解析領域内部, $S_{F}$ : 自 由表面, $S_{B}$ : 海底面, $S_{H}$ : 構造物表面である. また, $n$ による微分は構造物表面に㧤ける法線方向微分を表わ す.

入射波は $\theta=0$ より入射し, 構造物が軸対称形である ことから, 散乱波も $\theta$ に関して対称, したがって $\theta$ の 偶関数でなければならない. さらに解は $\theta$ に関して周 期 $2 \pi$ の周期関数であることも明らかである. $\theta$ に関す るこれらの性質から， $\phi_{\mathrm{sc}}$ を次のようにフーリエ余弦級 数で表わす.

$$
\phi_{\mathrm{sc}}(r, \theta, z)=\sum_{m=0}^{\infty} \varphi^{(m)}(r, z) \cdot \cos m \theta
$$

ここに, $\varphi^{(m)}(r, z)$ は, $m$ 次のフーリエ倸数で, $r$ と $z$ の関数である.

これを, 式 (3) に代入すると, $\varphi^{(m)}(r, z)$ に関して 次の偏微分方程式を得る.

$$
\frac{\partial^{2} \varphi^{(m)}}{\partial r^{2}}+\frac{1}{r} \frac{\partial \varphi^{(m)}}{\partial r}-\frac{m^{2}}{r^{2}} \varphi^{(m)}+\frac{\partial^{2} \varphi^{(m)}}{\partial z^{2}}=0
$$

また，同様に式 (4)，(5)，(7) より， $\varphi^{(m)}(r, z)$ に関 する次の境界条件および放射条件が得られる。

$$
\begin{aligned}
& \left.\partial \varphi^{(m)} / \partial z-\left(\omega^{2} / g\right) \varphi^{(m)}=0 \quad \text { (on } S_{F}\right) \\
& \left.\partial \varphi^{(m)} / \partial z=0 \quad \text { (on } S_{B}\right) \\
& \lim _{r \rightarrow \infty} r^{1 / 2}\left(\partial \varphi^{(m)} / \partial r-i k_{0} \varphi^{(m)}\right)=0 \cdots \cdots
\end{aligned}
$$

式（9）（12）を満たす解を，固有関数の 重ね合わせ による無限級数の形で求めると次式となる.

$$
\begin{aligned}
\varphi^{(m)}(r, z)= & \sum_{n=1}^{\infty} A_{n}{ }^{(m)} \cdot \frac{\cos k_{n}(h+z)}{\cos k_{n} h} \cdot K_{m}\left(k_{n} r\right) \\
& -i A_{0}{ }^{(m)} \frac{\cosh k_{0}(h+z)}{\cosh k_{0} h} \cdot H_{m}{ }^{(2)}\left(k_{0} r\right)
\end{aligned}
$$

ここに, $A_{n}{ }^{(m)}(n, m=0,1, \cdots)$ : 複素末定係数, $k_{n}(n=$ $1,2, \cdots)$ : 固有值 ( $k_{n} \tan k_{n} h=-\omega^{2} / g$ の実正根), $K_{m}$ : 第 2 種変形ベッセル関数, $H_{m}{ }^{(2)}$ : 第 2 種ハンケル関数 である。

散乱波のポテンシャル関数 $\phi_{\mathrm{sc}}$ は, 式 (13) を式 (8) に代入することにより，次式のごとく表わされる.

$$
\phi_{\mathrm{sc}}(r, \theta, z)=\sum_{m=0}^{\infty}\left\{\sum_{n=1}^{\infty} A_{n}{ }^{(m)} \cdot \frac{\cos k_{n}(h+z)}{\cos k_{n} h}\right.
$$




$$
\left.\cdot K_{m}\left(k_{n} r\right)-i A_{0}{ }^{(m)} \frac{\cosh k_{0}(h+z)}{\cosh k_{0} h} \cdot H_{m}{ }^{(2)}\left(k_{0} r\right)\right\}
$$$$
\cdot \cos m \theta
$$

これは，構造物表面の境界条件（6）を除いた，基礎 方程式 (3), および, 自由表面条件 (4), 海底の不透過 条件 (5), 無限遠における放射条件（7）を満たしてお り, 任意の軸対称構造物による散乱波の一般解である.

\section{（2）構造物表面条件の固有関数による展開と末定係 数の決定}

一般解 (14) における末定係数 $A_{n}{ }^{(m)}(n, m=0,1, \cdots)$ は, 個々の構造物形状に応じて, 式 (14) が構造物表面 の不透過条件（6）を満足するように決めればよい．こ こでは，この方法について述べる.

散乱波のポテンシャル関数 $\phi_{\mathrm{sc}}$ を式 (8) のごとくフ ーリエ余弦展開したのに応じて, 入射波のポテンシャル 関数 (2) \&フーリエ余弦展開する.これには, 式 (2) 中の指数関数の部分がベッセル関数を用いて, 次のよう に展開できることを用いる ${ }^{20)}$.

$$
e^{i k_{0} r \cos \theta}=\sum_{m=0}^{\infty} \epsilon_{m} i^{m} \cos m \theta \cdot J_{m}\left(k_{0} r\right)
$$

ここに, $\epsilon_{m}$ : ノイマン数 $(m=0$ のとき $1, m \geq 1$ のと き 2$), J_{m}$ : 第 1 種ベッセル関数である.

したがって, 式 (15) を式 (2) に代入し, フーリエ係 数として $\varphi_{\mathrm{in}}{ }^{(m)}$ を次のように定義すると, 入射波のポ テンシャル関数 $\phi_{\text {in }}$ もフーリエ余弦展開できたことに なる.

$$
\left\{\begin{array}{r}
\varphi_{\mathrm{in}}{ }^{(m)}(r, z)=\epsilon_{m} i^{m} \frac{\cosh k_{0}(h+z)}{\cosh k_{0} h} J_{m}\left(k_{0} r\right) \\
\ldots \ldots \ldots \ldots \ldots \ldots \ldots \ldots \ldots \ldots \ldots \ldots \ldots \ldots \ldots \ldots \ldots \ldots \ldots \ldots \ldots \ldots \ldots
\end{array}\right.
$$

一方，構造物表面上の法線方向微分 $\partial / \partial n$ は，一般に 単位法線ベクトルの $r, \theta, z$ 成分, $n_{r}, n_{\theta}, n_{z}$ を用いて 表わすことができるが, 軸対称構造物の場合, 表面上で 常に $n_{\theta}=0$ なので,

$$
\left.\partial / \partial n=n_{r} \cdot \partial / \partial r+n_{z} \cdot \partial / \partial z \text { (on } S_{H}\right)
$$
となる。

したがって, 構造物表面の不透過条件（6）は，各フ ーリエ成分に関して次のようになる.

$$
\begin{aligned}
n_{r} \frac{\partial \varphi^{(m)}}{\partial r}+ & n_{z} \frac{\partial \varphi^{(m)}}{\partial z} \\
=- & \left(n_{r} \frac{\partial \varphi_{\text {in }}{ }^{(m)}}{\partial r}+n_{z} \frac{\partial \varphi_{\text {in }}{ }^{(m)}}{\partial z}\right) \\
& \left(m=0,1, \cdots ; \text { on } S_{H}\right) \cdots \cdots .
\end{aligned}
$$

式 (13)，(16) をそれぞれ $r, z$ で偏微分してこれに代入 し, 未定係数 $A_{n}{ }^{(m)}(n=0,1, \cdots)$ について整理すると， $-i\left\{n_{r} \cdot \cosh k_{0}(h+z) \cdot H_{m}{ }^{\prime(2)}\left(k_{0} r\right)\right.$

$$
\left.-n_{z} \cdot k_{0} \cdot \sinh k_{0}(h+z) H_{m}{ }^{(2)}\left(k_{0} r\right)\right\} \cdot A_{0}{ }^{(m)}
$$

$+\sum_{n=1}^{\infty}\left[\left(\cosh k_{0} h / \cos k_{n} h\right) \cdot\left\{n_{r} \cdot \cos k_{n}(h+z)\right.\right.$

- $\left.K_{m}{ }^{\prime}\left(k_{n} r\right)-n_{z} \cdot k_{n} \cdot \sin k_{n}(h+z) \cdot K_{m}\left(k_{n} r\right)\right\}$

$\left.\cdot A_{n}{ }^{(m)}\right]=-\epsilon_{m} \cdot i^{m} \cdot\left\{n_{r} \cdot \cosh k_{0}(h+z)\right.$

- $\left.J_{m}{ }^{\prime}\left(k_{0} r\right)+n_{z} \cdot k_{0} \cdot \sinh k_{0}(h+z) \cdot J_{m}\left(k_{0} r\right)\right\}$

$$
\left(m=0,1, \cdots ; \text { on } S_{H}\right)
$$

となる.ただし, $K_{m}{ }^{\prime}\left(k_{n} r\right), H_{m}{ }^{\prime(2)}\left(k_{0} r\right), J_{m}{ }^{\prime}\left(k_{0} r\right)$ な どは，それぞれ $r$ に関する微分を表わす.

式 (20) は，構造物表面の不透過条件（6）をフーリエ 余弦展開したとき, 各フーリエ次数ごとに満たすべき関 係式で, 構造物上における任意 の $r, z$ につて成り立つ必要 がある。

ところで, 軸対称構造物にお いては，構造物表面で $n_{r}, n_{z}$ ， $r$ 等は $\theta$ に無関係であり, $z$ の みによって決まる(図一2参 照). すなわち, $n_{r}, n_{z}, r$ 等は すべて $-h \leq z \leq 0$ なる $z$ の 関数と考えることができ，これ

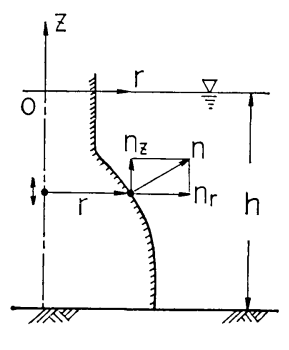

図一2 構造物表面にお ける $\boldsymbol{n}_{r}, \boldsymbol{n}_{z}, \boldsymbol{r}$ を,

$$
\left\{\begin{array}{l}
n_{r}=n_{r}(z) \\
n_{z}=n_{z}(z) \quad(-h \leq z \leq 0) \\
r=R(z)
\end{array}\right.
$$

と表わす.

したがって, 式 (20) の両辺は見掛け上 $r$ と $z$ 関数 であるが, 実際はともに $z$ みの関数であって, 境界条 件 (6) が，構造物上の任意の点で成り立つということ と, 式 (20) が $m=0,1, \cdots$ に対して, $-h \leq z \leq 0$ な る任意の $z$ につて成り立つということは同值である.

ここで,

$$
\begin{aligned}
& F_{n}{ }^{(m)}(z)= \\
& \qquad \begin{array}{l}
-i\left\{n_{r}(z) \cdot \cosh k_{0}(h+z)\right. \\
\cdot H_{m}{ }^{\prime(2)}\left(k_{0} R(z)\right)+n_{z}(z) \cdot k_{0} \cdot \sinh k_{0}(h+z) \\
\left.\cdot H_{m}{ }^{(2)}\left(k_{0} R(z)\right)\right\} \quad(n=0) \\
\left(\cosh k_{0} h / \cos k_{n} h\right)\left\{n_{r}(z) \cdot \cos k_{n}(h+z)\right. \\
\cdot K_{m}{ }^{\prime}\left(k_{n} R(z)\right)-n_{z}(z) \cdot k_{n} \cdot \sin k_{n}(h+z) \\
\left.\cdot K_{m}\left(k_{n} R(z)\right)\right\} \quad(n=1,2, \cdots)
\end{array}
\end{aligned}
$$

$$
G^{(m)}(z)=-\epsilon_{m} i^{m}\left\{n_{r}(z)\right.
$$$$
\cdot \cosh k_{0}(h+z) \cdot J_{m}{ }^{\prime}\left(k_{0} R(z)\right)
$$$$
+n_{z}(z) \cdot k_{0} \cdot \sinh k_{0}(h+z)
$$$$
\text { - } \left.J_{m}\left(k_{0} R(z)\right)\right\}
$$

とおくと, 式（20）は次のように表わされる.

$$
\sum_{n=0}^{\infty} A_{n}{ }^{(m)} \cdot F_{n}^{(m)}(z)=G^{(m)}(z) \quad(m=0,1, \cdots)
$$

この両辺は, すでに述べたとおり $-h \leq z \leq 0$ で定 
義された $z$ の関数である. 任意の関数が固有関数で展開

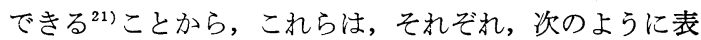
わすことができる.

$$
\begin{aligned}
& \int \sum_{n=0}^{\infty} A_{n}{ }^{(m)} \cdot F_{n}{ }^{(m)}(z)=b_{0}{ }^{(m)} \cdot \cosh k_{0}(h+z) \\
& +\sum_{l=1}^{\infty} b_{l}{ }^{(m)} \cdot \cos k_{l}(h+z) \\
& G^{(m)}(z)=c_{0}{ }^{(m)} \cdot \cosh k_{0}(h+z) \\
& +\sum_{l=1}^{\infty} c_{l}{ }^{(m)} \cdot \cos k_{l}(h+z)
\end{aligned}
$$

ただし， $b_{l}^{(m)}, c_{l}{ }^{(m)}(l, m=0,1, \cdots)$ は，フーリエ式係 数で以下のようである.

$$
\begin{gathered}
b_{l}^{(m)}=\left\{\begin{array}{c}
\sum_{n=0}^{\infty} A_{n}{ }^{(m)} \cdot \int_{-h}^{0} F_{n}^{(m)}(z) \cdot \cosh k_{0}(h+z) d z \\
\cdot / \int_{-h}^{0} \cosh ^{2} k_{0}(h+z) d z \quad(l=0) \\
\sum_{n=0}^{\infty} A_{n}(m) \cdot \int_{-h}^{0} F_{n}^{(m)}(z) \cdot \cos k_{l}(h+z) d z \\
\cdot / \int_{-h}^{0} \cos ^{2} k_{l}(h+z) d z \quad(l=1,2, \cdots)
\end{array}\right. \\
c_{l}^{(m)=}\left\{\begin{array}{c}
\int_{-h}^{0} G^{(m)}(z) \cdot \cosh k_{0}(h+z) d z \\
\cdot / \int_{-h}^{0} \cosh ^{2} k_{0}(h+z) d z \quad(l=0) \\
\int_{-h}^{0} G^{(m)}(z) \cdot \cos _{l} k_{l}(h+z) d z \\
\cdot / \int_{-h}^{0} \cos ^{2} k_{l}(h+z) d z \quad(l=1,2, \cdots)
\end{array}\right.
\end{gathered}
$$

式（20）あるいは式 (24) が, $-h \leq z \leq 0$ なる任意 の $z$ について成り立つためには, 固有関数展開した各次 数の係数が等しくなければならない.

したがって，式 (27)，(28）より次式を得る.

$$
\left\{\begin{array}{r}
\sum_{n=0}^{\infty} A_{n}{ }^{(m)} \cdot \int_{-h}^{0} F_{n}^{(m)}(z) \cdot \cosh k_{0}(h+z) d z \\
=\int_{-h}^{0} G^{(m)}(z) \cdot \cosh k_{0}(h+z) d z \cdots \cdots \\
\sum_{n=0}^{\infty} A_{n}{ }^{(m)} \cdot \int_{-h}^{0} F_{n}^{(m)}(z) \cdot \cos k_{l}(h+z) d z \\
=\int_{-h}^{0} G^{(m)}(z) \cdot \cos k_{l}(h+z) d z \\
(l=1,2, \cdots) \cdots \cdots \cdots
\end{array}\right.
$$

式 (29)，(30）を行列表示すると，次のようになる.

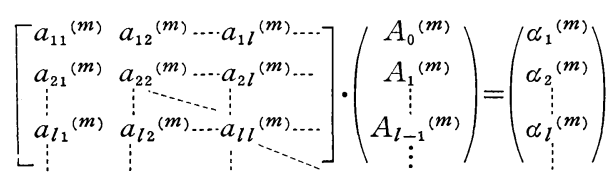$$
(m=0,1, \cdots)
$$

ただし, 行列の要素 $a_{l s}{ }^{(m)}$, および, ベクトルの要素 $\alpha_{l}^{(m)}$ は次式で表わされる.

$$
\begin{gathered}
a_{l s}{ }^{(m)}=\left\{\begin{array}{r}
\int_{-h}^{0} F_{s-1}{ }^{(m)}(z) \cdot \cosh k_{0}(h+z) d z \\
\int_{-h}^{0} F_{s-1}{ }^{(m)}(z) \cdot \cos k_{l-1}(h+z) d z \\
(l=1, s \geq 1)
\end{array}\right. \\
\alpha_{l}{ }^{(m)}=\left\{\begin{array}{rr}
(m=0,1, \cdots) \cdots \cdots \cdots \cdots(32) \\
\int_{-h}^{0} G^{(m)}(z) \cdot \cosh k_{0}(h+z) d z & (l=1) \\
\int_{-h}^{0} G^{(m)}(z) \cdot \cos k_{l-1}(h+z) d z & (l \geq 2)
\end{array}\right.
\end{gathered}
$$

式 (31) は，未定係数 $A_{n}{ }^{(m)}(n=0,1, \cdots)$ が満たす心゙ き 無限次元複素係数連立 1 次方程式である. 一般解 （14）における 固有関数列は, 収束級数をなすので, フ 一リエ項の各次数ごとに, 式 (31) を適当な $n$ について 解けば，未定係数が定まる.

そして, 以上の展開の過程から明らかなように, 得ら れた $A_{n}{ }^{(m)}$ を用いた式 (14) は，基礎方程式と，構造 物表面の不透過条件（6）を含む，すべての 境界条件を 満足する解である.

流体運動を支配する場全体の速度ポテンシャルは, 式 （1）に，式 (14)，(16)，(17）などを代大することによっ て得られ，次式となる.

$$
\begin{aligned}
& \Phi(r, \theta, z, t)=\frac{g H_{0}}{2 \omega} \sum_{m=0}^{\infty}\left[\left\{\epsilon_{m} i^{m} J_{m}\left(k_{0} r\right)\right.\right. \\
& \left.-i A_{0}{ }^{(m)} \cdot H_{m}{ }^{(2)}\left(k_{0} r\right)\right\} \cdot \frac{\cosh k_{0}(h+z)}{\cosh k_{0} h} \\
& \left.+\sum_{n=1}^{\infty} A_{n}^{(m)} \cdot \frac{\cos k_{n}(h+z)}{\cos k_{n} h} \cdot K_{m}\left(k_{n} r\right)\right] \\
& \text { - } e^{i \omega t} \cdot \cos m \theta
\end{aligned}
$$

\section{（3）波圧，波力および波高}

波圧 $p$ は, ベルヌーイの定理において, 2 次の微小 項を無視し, 変動成分のみを取り出すと, 式 (34) の速 度ポテンシャルを用いて，

$$
p=-i \rho \omega \Phi(r, \theta, z, t)
$$

と表わすことができる．ここに， $\rho$ : 流体密度である.

水深 $z$ における, 構造物の単位長さ当たりに働く流体 力を $\boldsymbol{f}$ とすると, 軸対称構造物であるから, この $y$ 成 分は明らかに0である. 他の成分については次式によっ て求められる.

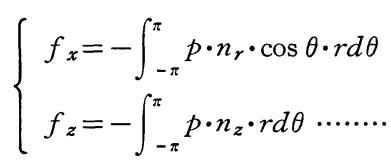

このうち, $f_{x}$ については, 式 (34), (35) などを式 （36）に代入して， $\theta$ に関する積分を実行すると，余弦 関数の直交性から， $m$ に関する級数項は $m=1$ の場合 を除いてすべて 0 となり, 結局, 


$$
\begin{aligned}
f_{x}= & -\frac{\rho g \pi H_{0}}{2} n_{r} \cdot r \cdot e^{i \omega t} \cdot\left[\left\{2 J_{1}\left(k_{0} r\right)\right.\right. \\
& \left.-A_{0}{ }^{(1)} \cdot H_{1}{ }^{(2)}\left(k_{0} r\right)\right\} \cdot \frac{\cosh k_{0}(h+z)}{\cosh k_{0} h} \\
& \left.+\sum_{n=1}^{\infty} A_{n}{ }^{(1)} \cdot K_{1}\left(k_{n} r\right) \frac{\cos k_{n}(h+z)}{\cos k_{n} h}\right]
\end{aligned}
$$

となる. 全波力 $F_{x}$ はこれを海底から水面まで積分す ることによって得られる.

次に，構造物下端まわりのモーメントを $\boldsymbol{M}$ とすると 構造物の対称性から, $x, z$ 成分は 0 である. $y$ 成分は次 式によって求められる.

$$
\begin{aligned}
M_{y}= & -\frac{\rho g \pi H_{0}}{2} e^{i \omega t} \int_{-h}^{0}\left[\left\{\left(2 J_{1}\left(k_{0} r\right)\right.\right.\right. \\
& \left.-A_{0}^{(1)} \cdot H_{1}^{(2)}\left(k_{0} r\right)\right) \cdot \frac{\cosh k_{0}(h+z)}{\cosh k_{0} h} \\
& \left.+\sum_{n=1}^{\infty} A_{n}^{(1)} \cdot K_{1}\left(k_{n} r\right) \frac{\cos k_{n}(h+z)}{\cos k_{n} h}\right\} \\
& \left.\cdot r\left\{n_{z} \cdot r-n_{r} \cdot(z+h)\right\}\right] d z \cdots \cdots \cdots \cdots
\end{aligned}
$$

これらからわかるように，水平波力あるいは転倒モー メントを求める際には, フーリエ項の第 2 項に対応する $m=1$ の場合についてのみ, 未定係数を定めればよいの で計算は著しく簡単となる。なお,ここで示した波力は ポテンシャル圧力による，、わゆる慣性力のみであるの で， $D / L$ が小さいときには，これ以外に抗力の影響を 考慮する必要がある.

構造物によって散乱された後の波高を $H$ とすると き, $H$ と入射波高 $H_{0}$ との比 $K_{d}\left(=H / H_{0}\right)$ は,

$$
\begin{aligned}
K_{d}= & \mid \sum_{m=0}^{\infty}\left\{\epsilon_{m} i^{m} J_{m}\left(k_{0} r\right)-i A_{0}{ }^{(m)} \cdot H_{m}{ }^{(2)}\left(k_{0} r\right)\right. \\
& \left.+\sum_{n=1}^{\infty} A_{n}{ }^{(m)} \cdot K_{m}\left(k_{n} r\right)\right\} \cdot \cos m \theta \mid \cdots \cdots(40)
\end{aligned}
$$

によって求められる.

\section{（4） 円筒の場合—MacCamy・Fuchs の理論解と の関連}

円筒構造物による波の回折・散乱を理論的に取り扱っ たものに MacCamy と Fuchs による研究があり ${ }^{22)}$, そ の解は円筒の半径を $r_{0}$ として次のように表わされる.

$$
\begin{gathered}
\Phi(r, \theta, z, t)=\frac{g H_{0}}{2 \omega} \cdot \frac{\cosh k_{0}(h+z)}{\cosh k_{0} h} \\
\cdot \sum_{m=0}^{\infty}\left[\epsilon _ { m } i ^ { m } \left\{J_{m}\left(k_{0} r\right)-\frac{J_{m}{ }^{\prime}\left(k_{0} r_{0}\right)}{H_{m}{ }^{\prime(2)}\left(k_{0} r_{0}\right)}\right.\right. \\
\left.\left.\cdot H_{m}{ }^{(2)}\left(k_{0} r\right)\right\} \cdot e^{i \omega t} \cdot \cos m \theta\right] \cdots \cdots \cdots \cdots \cdots . . . \cdots \cdots
\end{gathered}
$$

一方, 本理論で対象としているのは, 軸対称構造物で あり，円筒はこの一例である．ここでは本理論を円筒構 造物に適用し, 上記の MacCamy·Fuchs の解が数学的 に導かれることを示す. そして,これにより, 本理論が
MacCamy・Fuchs の理論を特別な場合として含む，拡 張された理論となっていることを明らかにする.

半径 $r_{0}$ の円筒構造物を考えると, 式 (21) に示した $n_{r}, n_{z}, r$ は，構造物表面で次のようになる.

$$
\left\{\begin{array}{l}
n_{r}(z)=1 \\
n_{z}(z)=0 \\
R(z)=r_{0}
\end{array} \quad(-h \leq z \leq 0)\right.
$$

したがって, 式 (22), (23) に示した $F_{n}{ }^{(m)}(z), G^{(m)}(z)$ は, 円筒に対して次式となる.

$$
\begin{aligned}
& F_{n}{ }^{(m)}(z)=\left\{\begin{array}{l}
-i \cosh k_{0}(h+z) \cdot H_{m}{ }^{\prime(2)}\left(k_{0} r_{0}\right) \quad(n=0) \\
\frac{\cosh k_{0} h}{\cos k_{n} h} \cdot \cos k_{n}(h+z) \cdot K_{m}{ }^{\prime}\left(k_{n} r_{0}\right)
\end{array}\right. \\
& (n=1,2, \cdots) \\
& G^{(m)}(z)=-\epsilon_{m} i^{m} \cosh k_{0}(h+z) \cdot J_{m}{ }^{\prime}\left(k_{0} r_{0}\right)
\end{aligned}
$$

これらを連立方程式 (31) の倸数行列の要素, および, ベクトルの要素の計算式 (32), (33) に代入し, 積分に 関係のない定数を積分の外に出すと, 次式が得られる.

$$
\begin{aligned}
& a_{l s}{ }^{(m)}= \\
& \left\{\begin{array}{r}
-i H_{m}{ }^{\prime(2)}\left(k_{0} r_{0}\right) \int_{-h}^{0} \cosh ^{2} k_{0}(h+z) d z \quad(l=s=1) \\
K_{m}{ }^{\prime}\left(k_{s-1} r_{0}\right) \frac{\cosh k_{0} h}{\cos k_{s-1} h} \int_{-h}^{0} \cos k_{s-1}(h+z) \\
\cdot \cosh k_{0}(h+z) d z \quad(l=1, s \geq 2) \\
-i H_{m}{ }^{(2)}\left(k_{0} r_{0}\right) \int_{-h}^{0} \cosh k_{0}(h+z) \\
\cdot \cos k_{l-1}(h+z) d z(l \geq 2, s=1) \\
K_{m}{ }^{\prime}\left(k_{s-1} r_{0}\right) \frac{\cosh k_{0} h}{\cos k_{s-1} h} \int_{-h}^{0} \cos k_{l-1}(h+z) \\
\cdot \cos k_{s-1}(h+z) d z(l, s \geq 2) \\
(m=0,1, \cdots) \cdots \cdots \cdots \cdots(45)
\end{array}\right.
\end{aligned}
$$

$\alpha_{l}^{(m)}=$

$$
\left\{\begin{array}{r}
-\epsilon_{m} i^{m} J_{m}^{\prime}\left(k_{0} r_{0}\right) \int_{-h}^{0} \cosh ^{2} k_{0}(h+z) d z \quad(l=1) \\
-\epsilon_{m} i^{m} J_{m}^{\prime}\left(k_{0} r_{0}\right) \int_{-h}^{0} \cosh k_{0}(h+z) \\
\cdot \cos k_{l-1}(h+z) d z(l \geq 2) \\
\quad(m=0,1, \cdots) \cdots \cdots \cdots(46)
\end{array}\right.
$$

さらに積分を実行すると, 固有関数の直交性から， $a_{l s}{ }^{(m)}=$

$$
\left\{\begin{array}{c}
\left\{\begin{array}{r}
-\frac{i}{4 k_{0}}\left(\sinh 2 k_{0} h+2 k_{0} h\right) \\
\cdot H_{m}{ }^{(2)}\left(k_{0} r_{0}\right) \quad(l=s=1) \\
\frac{\cosh k_{0} h}{4 k_{l-1} \cos k_{l-1} h} \cdot\left(\sin 2 k_{l-1} h+2 k_{l-1} h\right) \\
\cdot K_{m}{ }^{\prime}\left(k_{l-1} r_{0}\right) \quad(l=s=2,3, \cdots)
\end{array}\right. \\
0 \quad(l \neq s) \quad
\end{array}\right.
$$$$
(m=0,1, \cdots)
$$

$\alpha_{l}^{(m)}=$ 


$$
\left\{\begin{array}{l}
-\frac{\epsilon_{m} i^{m}}{4 k_{0}}\left(\sinh 2 k_{0} h+2 k_{0} h\right) J_{m}{ }^{\prime}\left(k_{0} r_{0}\right) \quad(l=1) \\
0 \quad(l=2,3, \cdots)
\end{array}\right.
$$$$
(m=0,1, \cdots)
$$

となる.

したがって，未定係数 $A_{n}{ }^{(m)}(n, m=0,1, \cdots)$ に関す る連立方程式（31）は，次のようになる.

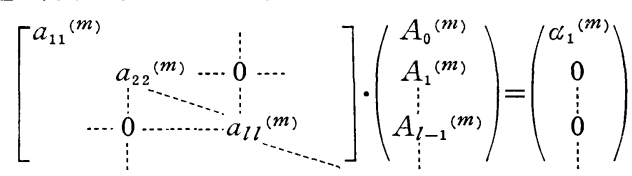$$
(m=0,1, \cdots)
$$

これは簡単に解けて, 次のような解を得る。

$$
A_{n}{ }^{(m)}=\left\{\begin{array}{l}
-i \epsilon_{m} i_{m} \frac{J_{m}{ }^{\prime}\left(k_{0} r_{0}\right)}{H_{m}{ }^{(2)}\left(k_{0} r_{0}\right)}(n=0) \\
0 \quad(n=1,2, \cdots)
\end{array}\right.
$$

$$
(m=0,1, \cdots)
$$

これを, 速度ポテンシャルの表示式 (34) に代入して 整理すると次式を得る.

$$
\begin{aligned}
\Phi(r, \theta, z, t)=\frac{g H_{0}}{2 \omega} \frac{\cosh k_{0}(h+z)}{\cosh k_{0} h} \\
\cdot \sum_{m=0}^{\infty}\left[\epsilon _ { m } i ^ { m } \left\{J_{m}\left(k_{0} r\right)-\frac{J_{m}{ }^{\prime}\left(k_{0} r_{0}\right)}{H_{m}{ }^{(2)}\left(k_{0} r_{0}\right)}\right.\right. \\
\left.\left.\cdot H_{m}{ }^{(2)}\left(k_{0} r\right)\right\} e^{i \omega t} \cdot \cos m \theta\right] \ldots \ldots \ldots \ldots . .
\end{aligned}
$$

これは先に示した MacCamy・Fuchs の解（41）にほか ならない.したがって, 本理論が MacCamy・Fuchs の理 論を包含した，より一般的な回折理諭となっていること が示された.

\section{3. 数值計算例と考察}

\section{（1） 不連続点の処理および級数の収束}

本理論の特徵は, 構造物表面上の法線ベクトルの成分 $n_{r}, n_{z}$, および, 構造物の中心軸から表面までの距離 $r$ を, $z$ の関数としてとらえ, 構造物表面における境界条 件を $z$ に関する固有関数で展開したところにある. $n_{r}$, $n_{z}, r$ などは, 構造物形状に対応して決まり, たと えば 図一3(a) に示すような境界が滑らかな構造物 では, $z$ の連続関数となる. しかし, 図一3(b) に示 すような構造物の場合は不連続な関数となり, 展開 項数を増やしても精度が上がらず, 逆に不連続点で 級数值が飛び出す Gibbs 現象 ${ }^{23}$ が現われるおそれ がある、これを避けるために, 実際の計算では図一 4 に破線で示したように, 不連続点を適当な勾配の 直線で結んだ関数㔙を用いることにし，後に示す貯 油タンク型構造物の計算の場合, 図中の $\Delta$ を 0.002 とした.これは構造物の角をわずかに丸めたことに
相当する. 不連続 点を有するその他 の構造物形状に対 しては元の形状を 損なわない程度の 範囲で $\Delta$ を変化 させ, 波力值の収 束をみてムの值 を決定すればよい であろう。

表一1 は，円す い台構造物につい て, 構造物の代表 径 $D$ と入射波長 $L$ との比 $D / L$ を変 えて, 各 $D / L$ に 対する

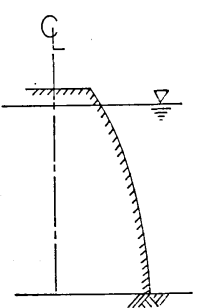

(c)

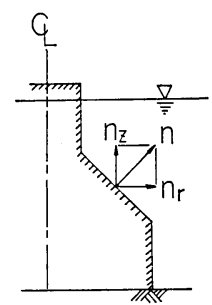

(b)
图一3 説 明 図

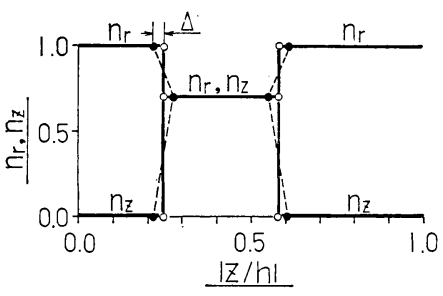

図一4 $\boldsymbol{n}_{r}, \boldsymbol{n}_{z}$ のグラフの例

$$
\varepsilon=|\varphi(M) \cdot \cos M \theta| \sum_{m=0}^{M} \varphi^{(m)} \cdot \cos m \theta \mid .
$$

\begin{tabular}{|c|c|c|c|c|c|c|}
\hline$M^{D / L}$ & 1.070 & 0.790 & 0.602 & 0.390 & 0.222 & \multirow{2}{*}{$\begin{array}{l}\mathrm{D} / \mathrm{h}=1.0 \\
\mathrm{~d}_{1} / \mathrm{d}_{2}=0.5\end{array}$} \\
\hline 1 & $3.7 \times 10^{\circ}$ & $1.2 \times 10^{0}$ & $2.2 \times 10^{0}$ & $1.6 \times 10^{0}$ & $5.3 \times 10^{0}$ & \\
\hline 2 & $1.5 \times 10^{1}$ & $9.5 \times 10^{\circ}$ & $1.5 \times 10^{1}$ & $2.7 \times 10^{1}$ & $7.9 \times 10^{0}$ & \multirow{3}{*}{$-d_{1}-1$} \\
\hline 3 & $2.6 \times 10^{0}$ & $2.2 \times 10^{0}$ & $6.7 \times 10^{0}$ & $7.6 \times 10^{-1}$ & $2.2 \times 10^{-1}$ & \\
\hline 4 & $2.6 \times 10^{0}$ & $3.1 \times 10^{-1}$ & $3.7 \times 10^{-1}$ & $3.0 \times 10^{-1}$ & $7.2 \times 10^{-2}$ & \\
\hline 5 & $5.5 \times 10^{-1}$ & $4.8 \times 10^{-2}$ & $8.8 \times 10^{-2}$ & $1.6 \times 10^{-2}$ & $2.2 \times 10^{-3}$ & \\
\hline 6 & $9.1 \times 10^{-2}$ & $1.0 \times 10^{-2}$ & $7.0 \times 10^{-3}$ & $3.2 \times 10^{-3}$ & $2.5 \times 10^{-4}$ & \\
\hline 7 & $1.3 \times 10^{-2}$ & $1.6 \times 10^{-3}$ & $1.1 \times 10^{-3}$ & $1.8 \times 10^{-4}$ & $8.1 \times 10^{-6}$ & \\
\hline 8 & $1.9 \times 10^{-3}$ & $2.2 \times 10^{-4}$ & $1.0 \times 10^{-4}$ & $1.8 \times 10^{-5}$ & $4.6 \times 10^{-7}$ & \\
\hline 9 & $3.4 \times 10^{-4}$ & $3.5 \times 10^{-5}$ & $9.0 \times 10^{-6}$ & $1.1 \times 10^{-6}$ & $1.6 \times 10^{-8}$ & \multirow{2}{*}{$f-d_{2}-1$} \\
\hline 10 & $4.7 \times 10^{-5}$ & $4.2 \times 10^{-6}$ & $2.3 \times 10^{-7}$ & $6.2 \times 10^{-8}$ & $5.0 \times 10^{-10}$ & \\
\hline
\end{tabular}

すなわち，式（14）におけるフーリエ級数の第 $M$ 項の 相対寄与率を示したものである.

この表より, 相対寄与率 $\varepsilon$ は, $M$ の増加に伴って桁 が1オーダーずつ小さくなっているのがわかる.

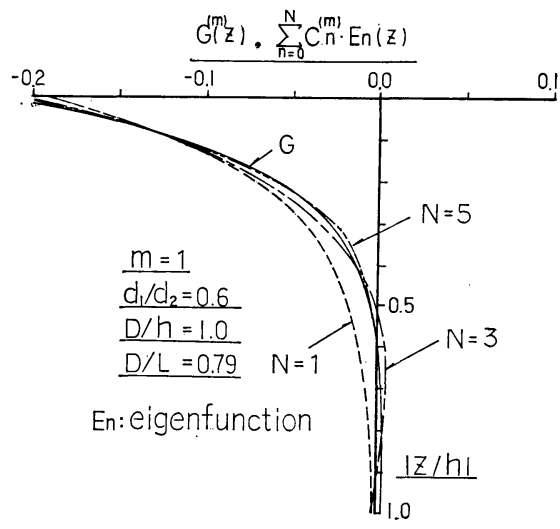

図一5 固有関数の展開項数と収束の例

\section{表一1 フーリェ展開における第 $\boldsymbol{M}$ 項の相対寄与率の例}


したがって, 級数を第 $M$ 項で打ち切ったために生じ る誤差は, 第 $M$ 項の值のオーダー程度であり，10 項 もとれば実用上十分な精度で収束すると考えられる。た だし，ここでは $d_{2}$ を代表径 $D$ としている.

図一5 は，やはり円すい台構造物の場合について, 式 (20) の右辺, すなわち式 (23) で表わされる $G^{(m)}(z)$ と, これを固有関数で展開した場合の式 (26) を, 展開 項数を変えて比較した一例である.ただし，それぞれの 実数部について示したもので, 綐軸は無次元化水深, 横 軸は関数值である.

この図にみられるように，この例の場合，N=5 程度 で十分に元の関数を近似できることがわかる.この固有 関数の展開項数については, 貯油タンク型構造物などに ついても検討したが，先に述べた不連続点の処理を行う ことによって，十数項をとれば十分であることがわかっ た.

これら以外の種々の形状, 特に不連続点を多く有する 複雑な形状に対しては, 展開項数も多くとる必要がある と考えられるので, それぞれ，展開項数と収束の関係を 検討する必要があろう. また, 固有関数展開における第 2 項以下の影響は, 構造物から離れるほど急速に小さく なるので, 波高分布計算の場合には, 構造物表面におけ る $G^{m}(z)$ を近似するのに必要な項数をとれば, 構造物 近傍も含めて十分な精度で計算することができる.

\section{（2） 円すい台による回折と波力}

軸対称構造物の例には, 海中展望塔, 水中タワー, 人 工島などが考えられるが，このような構造物の一般的形 状は円すい台と考えることができよう.

このような円すい台構造物に㗢く波力の特性を示した のが 図一6,7 である.これらは, 全波力 $F_{x}$, および,

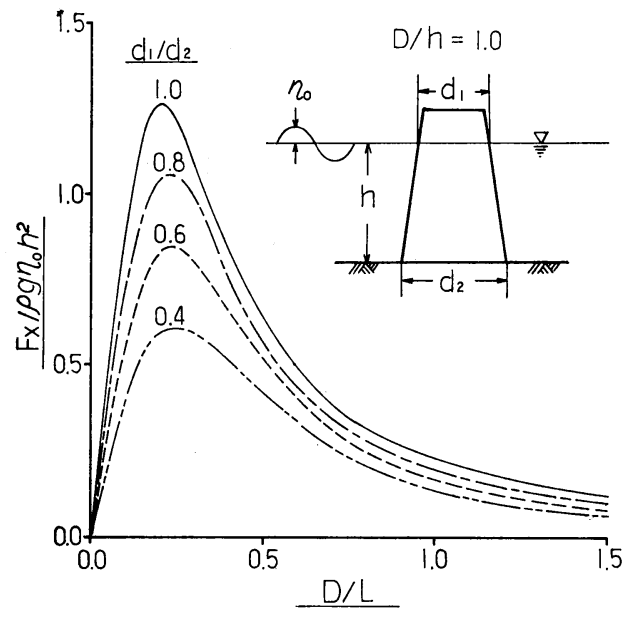

図一6 タワー權造物の全波力特性 $\left(d_{1} / d_{2}\right.$ による比較)
転倒モーメント $M_{\boldsymbol{y}}$ の無次元値と, 構造物の代表径 $D$ と入射波長 $L$ の比 $D / L$ の関係を, 上面と下面の径の 比 $d_{1} / d_{2}$ をパラメーターとして示したものである.ここ で, $d_{1} / d_{2}=1.0$ は 円筒の場合である. また, 代表径と して $d_{2}$ をとっている.

これらの図にみられるように, 円すい台構造物の波力 特性は, 全波力, 転倒モーメントともに, 円筒の場合に 類似していることがわかる.そして，これらは $d_{1} / d_{2}$ が 小さくなるに従って, $D / L$ のすべての值に対して小さ くなっている.

図一8，9 は，円すい台構造物周辺の 波高分布の一例 を, $d_{1} / d_{2}=0.5, D / h=1.14$ の場合について, 式 (40) より求められる入射波高比 $K_{d}\left(=H / H_{0}\right)$ で示したもの

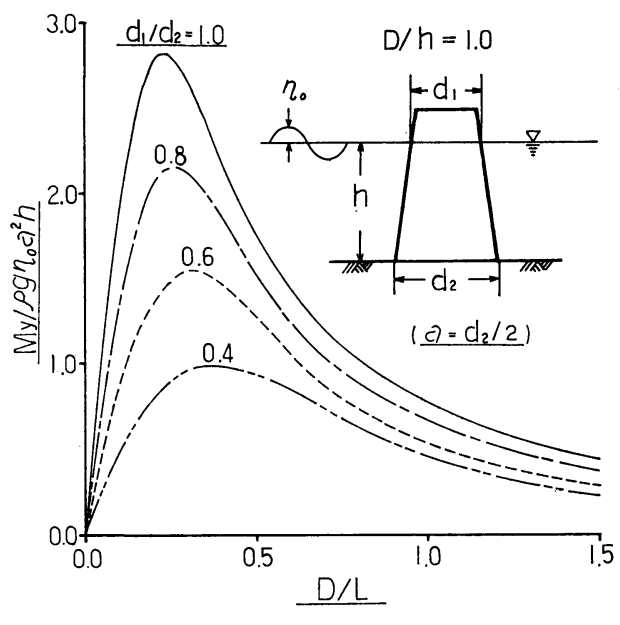

図一7 タワー構造物の転倒モーメント特性 $\left(d_{1} / d_{2}\right.$ による比較 $)$

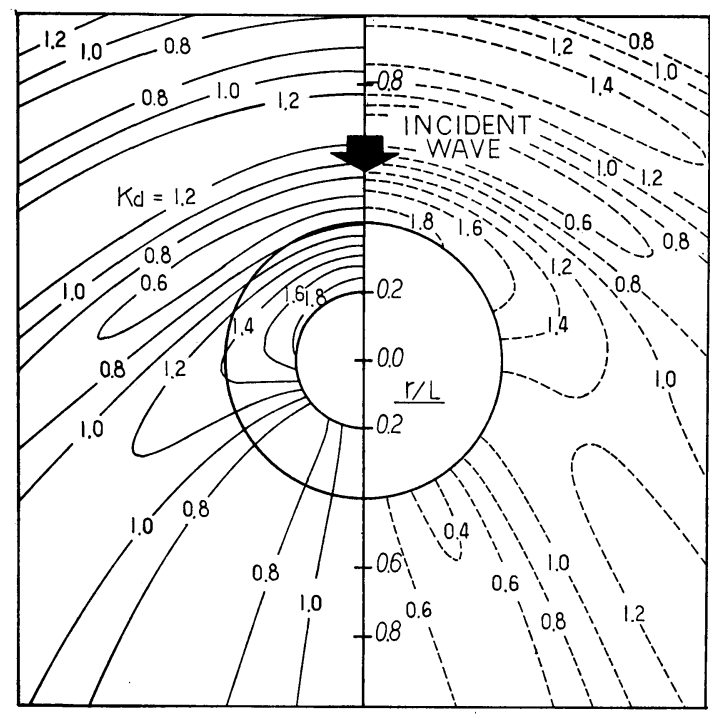

図一8 波高分布の例 $(D / L=0.80, D / h=1.14$ ， $d_{1} / d_{2}=0.5$ ) 


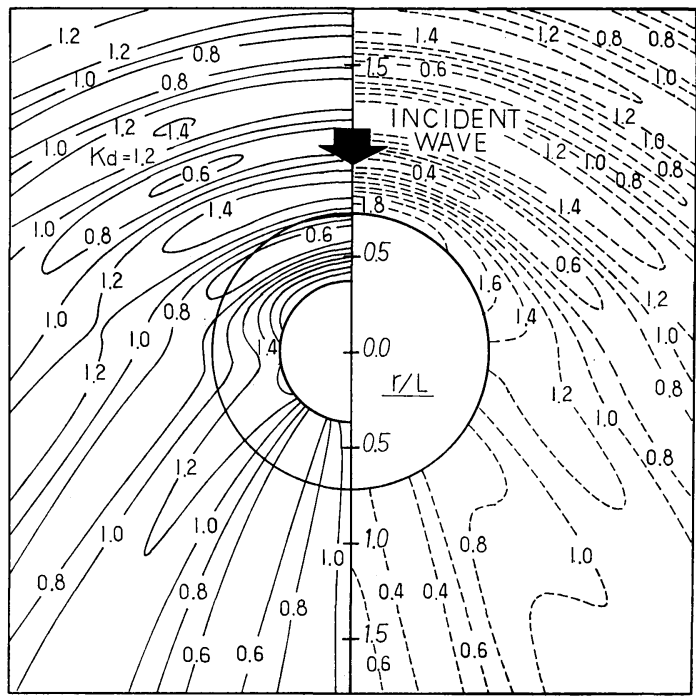

図-9 波高分布の例 $(D / L=1.42, D / h=1.14$, $\left.d_{1} / d_{2}=0.5\right)$

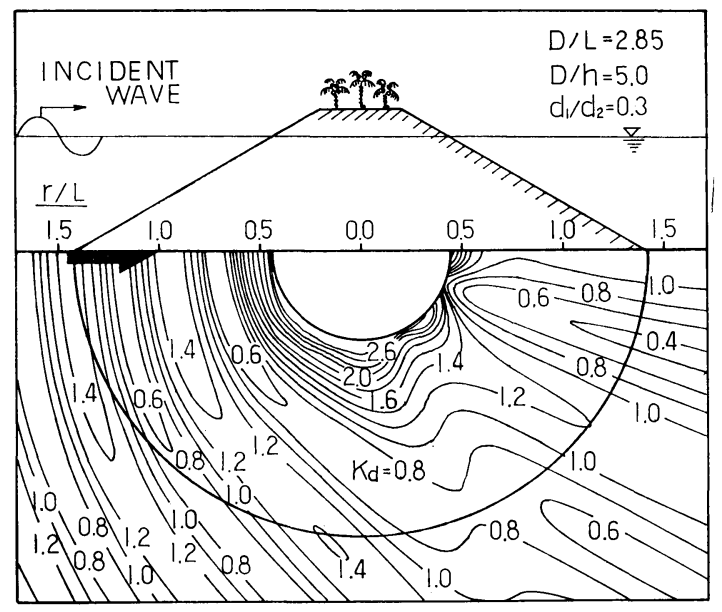

図一10 島周辺の波高分布例

であり，それぞれ， $D / L=0.80,1.42$ の場合である.ま た，それぞれの図中，右側に破線で示したのは，円すい 台の底面と同じ直径を有する円筒構造物による回折図で ある。

それぞれの場合について構造物前面に部分重復波が形 成されており, 円すい台前面ののり面における重復波の 節は，円筒の場合に比較して，わずかに短い位置に生じ ることがわかる，そしてこれは， $D / L$ が大きい 図一9 の場合，より顕著である．すなわち，円すい台前面で は， $D / L$ が大きくなると， 円筒などの直立構造物に比 較して波形勾配が大きくなることがわかる.

図一10 は，やはり円すい台周辺の波高分布の一例で, 人工島，あるいは小さな火山島を想定したものである. この場合， $D / L=2.85$, および, $D / h=5.0$ である.
計算結果をみると，波高は島の近傍で入射波高の 2.6 倍となっており，しかも，島の側面から後面にかけても 増大しているのがわかる．したがって，この場合，島の 周辺全域で砕波が助長される. 実際, 八ワイのオアフ島 の例にみるように，火山島の周辺で波高が増大し，砕波 を起こすことはよく知られており，ここで示した計算例 からも，このことが理解されよう。

これらの波力特性㧍よび波高分布から，円すい台のよ うな構造物の場合, 円筒構造物に比較して, 全波力, 転 倒モーメントなどは小さいが，斜面の効果により，周辺 で波形勾配が大きくなるため，砕波が生じる可能性が大 となるといえよう。

\section{（3） 貯油タンク型構造物の波力}

図一11 は軸対称型貯油タンクの例である.ここでは, この波力特性について, 図中に示したタンク天端の没水 深比 $q$ を固定して, タワー部とタンク部の径の比 $d_{1} / d_{2}$ を変えた場合，および， $d_{1} / d_{2}$ を固定して $q$ を変えた場 合について検討する.

図一12,13 は, $q$ を 0.5 に固定して $, d_{1} / d_{2}=1,1 / 2$, $1 / 3,1 / 6$ の場合について, 全波力 $F_{x}$ 抢よび転倒モーメ ント $M_{y}$ を $D / L$ との関倸でとらえたものである.た

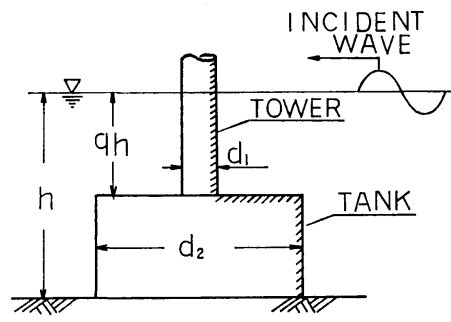

図一11軸対称貯油タンクの例

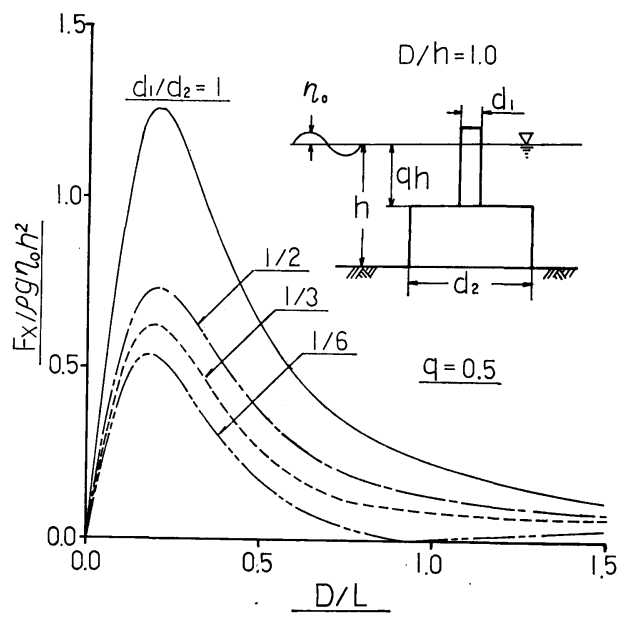

図一12 貯油タンク型構造物の全波力特性 $\left(d_{1} / d_{2}\right.$ による比較 $)$ 


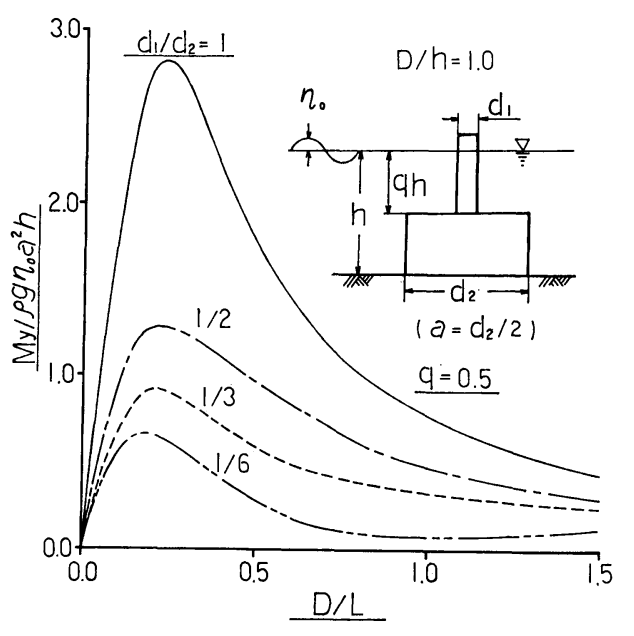

図一13 貯油タンク型構造物の転倒モーメント 特性 $\left(d_{1} / d_{2}\right.$ による比較 $)$

だし， $D$ はタンクの代表径で $L$ は入射波長である.こ こでは $D=d_{2}$ としている.

これらの図から, 全波力, 転倒モーメントともに, $d_{1} / d_{2}=1 / 6$ の場合を除いて, $D / L$ の増加に 伴って急激 に大きくなり, $D / L=0.2$ 付近でピークに達した後に一 様に減少するのがわかる. しかし， $d_{1} / d_{2}=1 / 6$ の場合 は, $D / L=0.95$ 付近に 極小值があり, この後, わずか ではあるが，また上昇している，これは，タワー部と夕 ンク部の径の比が小さくなると, 両者に作用する波力の 位相差が拡大され, その結果, タワー部とタンク部で波 力の作用する方向が逆向きとなり, これらの波力が互い に打ち消し合うためである.

図-14, 15 は, $d_{1} / d_{2}$ を $1 / 6$ に固定し, $q=0.0,0.3$, 0.5 の場合について, 波力特性を示したもので, 図中で 用いた記号の意味は前例と同じである.

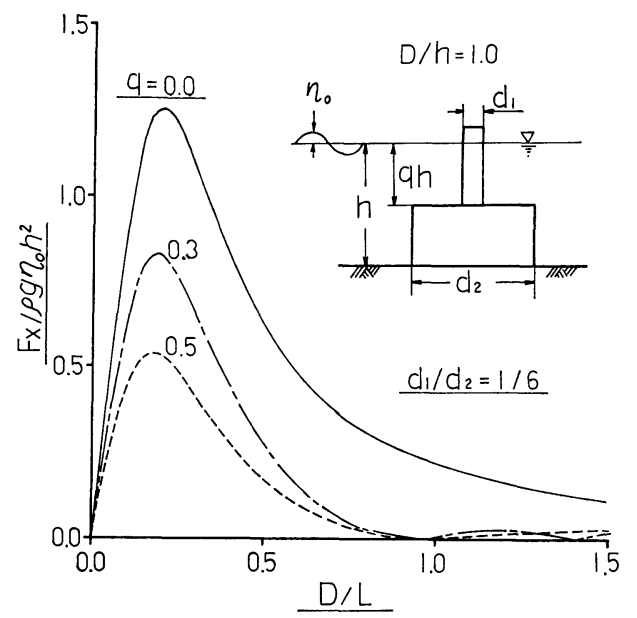

図一14 貯油タンク型構造物の全波力特性 ( $\boldsymbol{q}$ による比較)

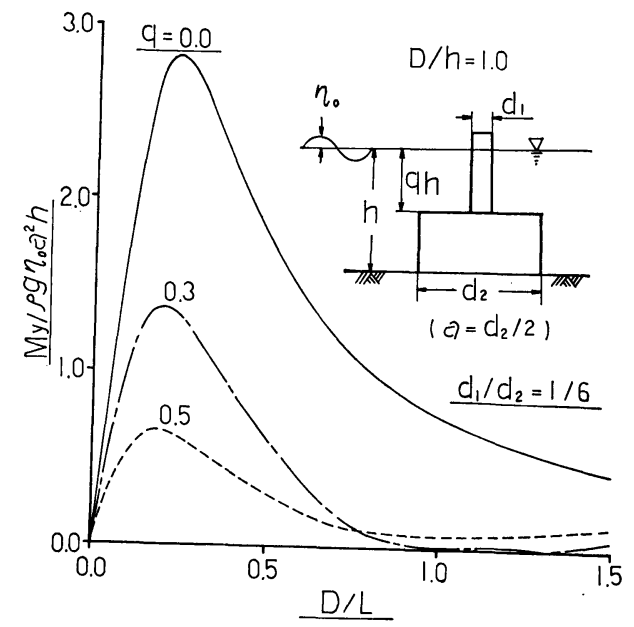

図一15 貯油タンク型構造物の転倒モーメント 特性 ( $q$ による比較)

図一14に示した 全波力特性をみると，波力が 0 とな る節が, $q=0.3$ の場合には $D / L=1.0,1.4$ 付近の 2 か 所にあり, $q=0.5$ の場合には, $D / L=0.95$ 付近の 1 か 所のみであるのがわかる. 波力が 0 となるのは, 上にも 述べたとおり，タワー部とタンク部に作用する波力に位 相差が生じ，これらが互いに相殺するためで，このよう にタワー部とタンク部で波力の位相が逆になることは $D / L$ の増加に伴っていくらでもあり得る.しかし， $D / L$ が大きく, したがって, 波長が構造物に比較して短くな ると, $h / L$ む大きくなり, 波は深海波となるため, 波に よる水粒子運動は平均水面に近い浅い部分のみとなって 深部では波力が働かなくなる.このためここで示した貯 油タンクの例では, ある波長以下になると, タンク部の 波力は小さくなり, 仮に逆位相としても, タワー部の波 力と相殺することができなくなる. そして, これは $d_{1} /$ $d_{2}$ が同じ場合にはタンク部が深部にあるほどいえるこ とであり，ここで示した計算例で，波力が 0 となる節 が, $q=0.3$ の場合 2 点であるのに対し, $q=0.5$ の場合 には 1 点であるのはこのためである.

また, $q=0$ で示される円筒の場合, 全波力, 転倒モ 一メントともに, ピークに達した後, 緩やかに減少して いるのに対し, $q=0.3,0.5$ の場合は, $D / L=0.5$ 付近 から急激に減少しているのがわかる.これは波長が短く なり，したがって $h / L$ が大きくなると, 深部に比べ, 水面付近の波力の影響が顕著になって, その部分の径が 全体波力に大きく影響するためである.したがって, 波 力の面だけからみると, 円筒のように一様断面のタンク よりも, 水深の深い部分に径の大きなタンク部を有し, 水面付近ではタワー部のみであるような形状が有利であ るといえよう。 


\section{4. 結語}

以上, 著者らは本論文において, 任意形状軸対称構造 物による微小振幅波の散乱と波力を, 固有関数展開およ びフーリエ展開によって厳密に取り扱い, これらの厳密 解を得る方法を示した. そして, 本理論を円筒構造物に 適用することによって, 本理論が, 円筒による回折・散 乱を扱った MacCamy•Fuchs の理論を包含したより 一般的な 理論であることを数学的に厳密に示した。 ま た, 一般的な 軸対称構造物に本理論を 適用した例とし て, 円すい台 (conical island) による波の回折と波力, および貯油タンク型構造物の波力などについて, 計算結 果を示し, 若干の考察を行った. これによって, 円すい 台形をした火山島・人工島などに波が進入すると, 波長 が短くなり波高は増大するなどのいくつかの興味深い結 果を示すことができた。

なお，本論文で示した解析法は，構造物表面における 境界条件を固有関数で展開するところに特徴があり，境 界上で展開するところから“境界展開法”ということが できよう．この “境界展開法” は，他の境界值問題にも 応用できると考えられ, 現在, 種々の適用例について検 討中である.

おわりに，本論文中の数值計算とそのとりまとめにつ いて, 清水建設 (株) 研究所, 大山 巧研究員の協力を 得たことを記して，謝意を表する次第である.

\section{参 考 文 献}

1) Morison, J.R., M.P. O'brien, J.W. Johnson and S.A. Schaaf: The force exerted by surface waves on piles, Petroleum Transactions, A.I.M.E., Vol. 189, 1950.

2) Garrison, C.J. : Hydrodynamic loading of large offshore structures; Three-dimensional source distribution methods, Numerical Methods in Offshore Engineering, John Wiley \& Sons, pp. 91 92, 1978.

3) MacCamy, R.C. and R.A. Fuchs : Wave forces on Piles; a diffraction theory, Tech. Memo., No. 69, Beach Erosion Board, pp. 1 17, 1954.

4）合田良美・吉村知司：島堤 および大型楕円柱体による波
の散乱と波力について，土木学会論文報告集，No. 205， 1972 .

5) Garrison, C.J. and Y.C. Philip : Wave forces on submerged bodies, Jour. of the waterways, Harbors and Coastal Eng. Div., Aug., 1972.

6）日野幹雄・藤崎治男 : 固定された海上構造物による波の 反射と透過一Green 関数による理論解, 第 20 回海岸工 学講演会論文集, pp. 101 106, 1973.

7） 日野幹雄・宮永洋一：グリーン関数 および 仮想法による 波力と波の回折計算, 土木学会論文報告集, No. 237 , pp. 51 62, 1975.

8）井島武士・周 宗仁・湯村やす：任意形状の透過および 不透過防波堤による 波の散乱と流体力, 土木学会論文報 告集, No. 225, 1974.

9）小林 浩・清川哲志：グリーン関数を用いた 任意形状構 造物に作用する波圧解析, 第 32 回土木学会年次講演会, 1977.

10）坂井藤一・河合三四郎：波動解析への有限要素法の適用, 第 20 回海岸工学講演会論文集, pp. 393 396, 1973.

11）瀬戸秀幸・山本善之：有限要素法による 定常波動の基礎 的研究, 日本造船学会論文集, No. 136, 1974.

12）山本善之・中野孝昭・光田哲久：有限要素法による 定常 波動問題の基礎的研究, 日本造船学会論文集, No. 140, 1976.

13）倉田克彦・井島武士：波動問題への 有限要素法の 適用, 第 26 回海岸工学講演会論文集, pp. 95〜99, 1979 .

14）瀬戸秀幸 : 有限要素法による 定常波動問題の基礎的研究 （第 3 報），日本造船学会論文集，No. 141，1977.

15）瀬戸秀幸：有限要素法による 定常波動問題の基礎的研究 （第 4 報），日本造船学会論文集，No. 144，1978.

16）瀬戸秀幸：New Hybrid Element Method による海洋構 造物に働く波力解析, 第 2 回流れの 有限要素解析 シンポ ジウム報文集, pp. 59 66, 1980.

17) Black, J.L. : Wave forces on vertical axisymmetric bodies, J.F.M., Vol. 67, Part 2, pp. 369 376, 1975.

18) Fenton, J.D. : Wave forces on vertical bodies of revolution, J.F.M., Vol. 85, Part 2, pp. 241 255, 1978

19）松井徹哉：軸対称構造物に作用する波力および散乱波の 解析, 建築学会学術講演会梗概集, 1978 .

20）寺沢寛一編：自然科学者のための数学概論 (応用編), 岩 波書店, pp. 528 530.

21）井島武士 : 最近の波浪理論における 境界値問題の解法と その応用, 1971 年度水工学に関寸る夏期研修会講義集, B-1-3, 1971.

22）前掲 3)

23）日野幹雄：スペクトル解析, 朝倉書店, pp. 10 13, 1977.

(1981.7.25 • 受付) 